\title{
Koningin Lear: Vlaamse Shakespeare getransformeer in Afrikaans
}

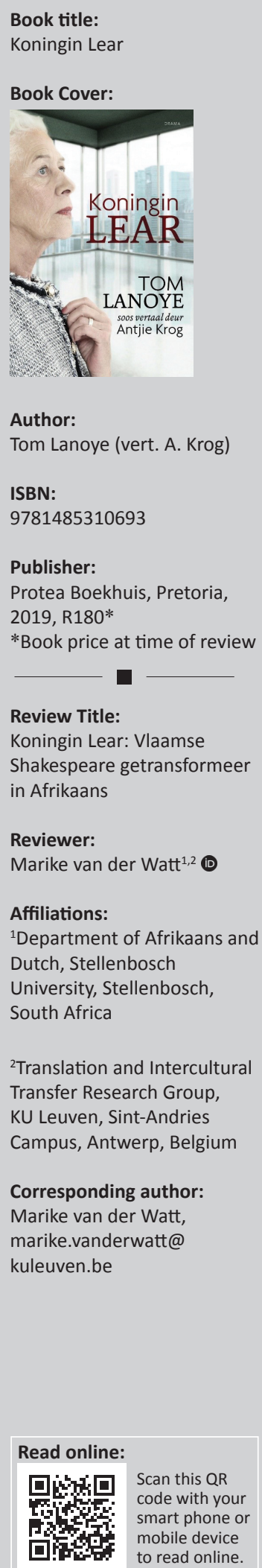

Die Vlaamse digter, skrywer en dramaturg, Tom Lanoye, is geen onbekende vir Suid-Afrikaanse lesers en teaterliefhebbers nie - trouens, hy is die mees vertaalde Nederlandstalige outeur in Afrikaans met sewe van sy werke wat sedert 1996 hier verskyn het. Koningin Lear is as opdragstuk vir die 25ste herdenking van die Klein Karoo Nasionale Kunstefees vertaal. Dit is in Maart 2019 vir die eerste keer in Afrikaans onder die regie van Marthinus Basson opgevoer met Antoinette Kellermann in die titelrol. Hierdie produksie is daarna met agt Kanna-toekennings bekroon, waarvan een aan Antjie Krog vir die 'uitnemende literêre bydrae' wat sy met die vertaling van die teks gelewer het. Danksy die finansiële steun van die Vlaams Fonds voor de Letteren het dit by Protea Boekhuis verskyn - een van die min dramatekste in Afrikaans wat dit tot op boekwinkels se rakke maak.

Koningin Lear is volgens die agterplat, "n herverbeelding van William Shakespeare se King Lear', en lewer onder meer skerp kommentaar op "n hedendaagse sakewêreld waarin integriteit en lojaliteit skaars kommoditeite geword het'. Dit sluit dus aan by Lanoye se vorige roman, Gelukkige slawe (2015a [vertaal deur Daniel Hugo]), waarin die korrupte bankwese ter sprake kom. Die bejaarde Elisabeth Lear is aan die stuur van 'n internasionale sakeryk, opgebou uit die konstruksiebedryf wat sy destyds van haar vader geërf het. Sy besluit om dit tussen haar drie seuns te verdeel, maar eers moet elke seun sy liefde en bewondering vir haar verklaar. Wanneer haar jongste seun aan die beurt kom, het hy verrassend genoeg niks om by sy ouer broers se lofsange te voeg nie. 'Die wins van niks is niks' (bl. 16), waarsku Elisabeth haar seun voor sý erfporsie tussen sy broers verdeel word. Dit word gaandeweg al hoe duideliker dat Elisabeth besig is om nie net haar houvas op die werklikheid te verloor nie, maar ook enige mag wat sy as geabdikeerde sakekoningin nog sou wou uitoefen. Terwyl sy haar lieflingseun verstoot het, blyk dit nou dat die twee oudstes se lofsange slegs lippediens was.

Lanoye behou sommige sleutelelemente van die Shakespeare-teks, soos die oomblik wanneer Lear die aankondiging maak dat die patrimonium in drie verdeel gaan word (Shakespeare 1972:62; Lanoye 2015b:12), die jongste kind se weiering om haar of sy liefde vir Lear voldoende te verwoord (Shakespeare 1972:64 \& Lanoye 2015b:16), en Lear se sterftoneel (Shakespeare 1972:182; Lanoye 2015b:139). Die oorspronklike teks met twee verhaallyne en 'n besetting van meer as 40 karakters, word tot ' $n$ enkele verhaallyn met nege karakters gekondenseer waar die koning, sy drie dogters en twee skoonseuns omgeskakel word na 'n matriarg, haar drie seuns en twee skoondogters. Die hofnar is nou Oleg, Lear se 'verpleër en geselskapsheer', terwyl Poor Tom as 'n 'daklose junkie' uitgebeeld word. Ten spyte van die verlies van die Gloucesterverhaallyn, kon Lanoye die belangrikste elemente daarvan op 'n verrassende wyse in sy verwerking van die drama inweef.

As vertaler druk Antjie Krog oudergewoonte haar eie stempel op die teks af (verwys gerus ook na Vosloo 2007 \& 2014 vir meer oor Krog as vertaler). Hoewel die bronteks, buiten die Vlaamse taal, nie aan 'n spesifieke gebied gekoppel kan word nie, lokaliseer Krog dit duidelik in Suid-Afrika. Lear waarsku Kent om nie tussen 'n 'leeuwyf en [ $h$ ]aar woede' (bl. 18) te kom staan nie (teenoor 'tijgerin en [h]aar furie' in die bronteks); vir die oudste seun, Gregory, is sy ma onder meer vir hom dierbaarder as 'rugby' en sy 'huis by Plet' (bl. 13) (teenoor 'voetbal op tv' en sy 'motorboot' in die bronteks), terwyl hulle kinders nie meer in 'n ongeïdentifiseerde stad skoolgaan nie, maar op Michael House [sic] (bl. 14). Soms lei die domestikering egter tot wollerigheid in die teks soos toe Cornald sy planne vir mikrofinansiering in ontwikkelende lande bekendmaak en dit as 'sybokhaarkous-verhaal' [sic] (bl. 19) afgemaak word. Die uitdrukking in die bronteks, 'geitenwollensokverhaal', verwys na 'personen die getuigen van een idealistische instelling die door menigeen als zweverig of onpraktisch wordt ervaren' (Etymologiedatabank s.d.) - presies

How to cite this book review: Van der Watt, M., 2019, 'Koningin Lear: Vlaamse Shakespeare getransformeer in Afrikaans', Literator 40(1), a1632. https://doi.org/10.4102/lit.v40i1.1632

Copyright: @ 2019 . The Authors. Licensee: AOSIS. This work is licensed under the Creative Commons Attribution License. 
hoe die oudste twee seuns hulle jongste broer sien. In Afrikaans roep sybokhaar egter eerder luukse klerasie of komberse op.

Hoewel die bronteks redelik ontdaan is van obseniteite, het Krog haar vertaling goed gepeper. Wanneer Lear vir Cornald onterf, verloop die tirade soos volg: 'Weg! Uit mijn gezicht! / Je geeft me niets? Dan krijg je niets, niets, níets.' In Afrikaans klink sy so: 'Gee pad jou klein stuk stront! / Niks - dis wat jy gee? By my kry jy dan: / Ook niks, zilch, zero, fokkol, níks' (bl. 18). Waar Lear in die Nederlandse teks vir Kent aansê om 'op te rotten', moet hy in Afrikaans 'gaan kak' (bl. 43). Daar is nog vele ander voorbeelde.

Wat karakterisering betref, het Krog in die dialekarsenaal gaan delf om vir Oleg, wat in die bronteks op grond van sy taalgebruik elders uit Europa afkomstig blyk te wees, 'n parmantige karakter met 'n kenmerkende Cape Flats-aksent te maak. Hy klink byvoorbeeld soos volg in die bronteks: 'De nieuwe medicijnen doen hun werk. Na die rampvergadering heeft ze dagenlang gezwalpt, nu duren de heldere momenten almaar langer', en in Afrikaans só: 'Her new medication works well. After that disaster van 'n meeting het sy dae lank net so op sulke waves gedryf, maar nou is haar clear moments al hoe langer' (bl. 39). Krog loop die risiko om van stereotipering beskuldig te word, maar sy stuit nie vir taboes nie, en hierdeur beweeg sy dalkjuis nader aan'n oorspronklike
Shakespeariaanse weergawe. Sy tree as 't ware op as eerste regisseur van die Afrikaanse drama en plaas dit binne haar eie performatiewe raamwerk wat grense - en die Afrikaanse teikengehoor - bly uitdaag.

In 'n tyd van staatskaping en Steinhoff-skandale, belig Koningin Lear die waansin wat in wolkekrabbers uitspeel en soos 'n virus tot in die strate versprei en die samelewing infekteer.

Vandag se koninkryke en monarge lyk miskien anders as dié waaroor Shakespeare dit gehad het, maar Lanoye (en Krog as die skepper van die Afrikaanse Lear-dinastie) slaag daarin om in 'n meer gestroopte teks die veelvlakkigheid van die oorspronklike werk te behou en die nuwe moontlikhede van die moderne konteks en besetting goed te ontgin.

\section{Literatuurverwysings}

Etymologiedatabank, s.d., Geitenwollensokken: Alternatief, wereldvreemd, halfzacht, besigtig op 13 Junie 2019, vanaf www.etymologiebank.nl/trefwoord/ geitenwollensokken.

Lanoye, T., 2015a, Gelukkige slawe, vert. D. Hugo, Protea Boekhuis, Pretoria.

Lanoye, T., 2015b, Koningin Lear, Prometheus, Amsterdam.

Shakespeare, W., 1972, King Lear, G.K. Hunter (ed.), Penguin, Harmondsworth.

Vosloo, F., 2014, 'Vertaling en/as abjeksie: Antjie Krog', Stellenbosch Papers in Linguistics Plus 43, 359-391.

Vosloo, F., 2007, “'Inhabiting" the translator's Habitus: Antjie Krog as translator', Current Writing: Text and Reception in Southern Africa 19(2), 72-93. 